\title{
Seasonal changes of the microplankton community along a tropical estuary
}

Seguro I. $^{\mathbf{a}^{*}}$, C.M. García ${ }^{\mathrm{a}}$, S. Papaspyrou ${ }^{\mathrm{a} 2}$, J.A. Gálvez ${ }^{\mathrm{a}}$, E. García-Robledo ${ }^{\mathrm{a} 3}$, G. Navarro $^{\mathrm{b}}$, S. Soria-Píriz ${ }^{\mathrm{a}}$, V. Aguilar $^{\mathrm{a}}$, O.G. Lizano ${ }^{\mathrm{c}, \mathrm{d}}$, A. Morales-Ramírez ${ }^{\mathrm{c}, \mathrm{e}}$, A. Corzo $^{\mathrm{a}}$ (1)

${ }^{a}$ Dpto. Biología. Facultad de Ciencias del Mar y Ambientales, Universidad de Cádiz, Pol. Río San Pedro s/n. 11510- Puerto Real, Cádiz, Spain

bInstituto de Ciencias Marinas de Andalucía (ICMAN-CSIC), Pol. Río San Pedro s/n, 11510 Puerto Real, Spain

${ }^{\mathrm{c}}$ Centro de Investigación en Ciencias del Mar y Limnología (CIMAR), P.O. Box 2060 San Pedro de Montes de Oca, Costa Rica

${ }^{\mathrm{d}}$ Escuela de Física, Universidad de Costa Rica. P.O. Box 2060 San Pedro de Montes de Oca, Costa Rica

${ }^{\text {e}}$ Escuela de Biología, Universidad de Costa Rica. P.O. Box 2060 San Pedro de Montes de Oca, Costa Rica

Present address:

${ }^{1}$ Centre for Ocean and Atmospheric Sciences, School of Environmental Sciences, University of East Anglia, Norwich, NR4 7TJ, United Kingdom

${ }^{2}$ Laboratorio de Microbiología y Genética, Departamento de Biomedicina, Biotecnología y Salud Pública, Facultad de Ciencias, Universidad de Cádiz,11510, Puerto Real, Spain.

${ }^{3}$ Microbiology, Department of Biosciences. University of Aarhus. Ny Munkegade 116, 4 DK-8000, Aarhus, Denmark * corresponding author:

Tel. +44 1603 59-3324

E-mail: i.seguro-requejo@uea.ac.uk 


\section{Abstract}

Microplankton organisms are an important link in the transfer of matter and energy between the benthic-pelagic microbial food web and higher trophic levels in estuaries. Although tropical estuaries are among the most productive aquatic systems globally, information on the spatial and seasonal dynamics of microplankton in such systems is scarce. In order to identify which variables control microplankton abundance and community structure a number of environmental variables were measured along the tropical Gulf of Nicoya (Costa Rica) during the rainy and dry seasons (2011-2012). The Tempisque River was a major source of nutrients and turbidity and thus imposing a clear gradient along the estuary. Chlorophyll $a$ (chl $a$ ) concentration was highest in the middle of the estuary $\left(2.7-20 \mathrm{mg} \mathrm{m}^{-3}\right)$, where turbidity decreased. The microplankton comprised mainly diatoms (88\%) and dinoflagellates (8\%). Multivariate analysis revealed five different microplankton assemblages associated with a seasonal and riverine-marine gradient, and supporting an ecotone model at the estuary head that shifts to an ecocline model for the rest of the estuary. Our results suggest that primary producers in the estuary were mainly limited by light rather than nutrients.

Keywords: Phytoplankton, biogeochemistry, tropical estuary, salinity, turbidity, diversity.

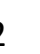

53

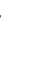

57

(6)

61

1

63

(6)

6




\section{Introduction}

Estuaries are among the most productive aquatic systems. These areas are important resources for the human population, being sometimes their only source of income (i.e. fishing). Estuaries are highly dynamic systems, undergoing from daily tidal changes to seasonal changes. This variability in time and space makes estuaries highly heterogeneous and complex ecosystems able to sustain high biodiversity levels (Attrill and Rundle 2002, Muylaert et al. 2009). Phytoplankton is a key constituent of estuaries, being a primary producer that highly influences water quality (i.e. eutrophication). In estuaries, seasonal phytoplankton dynamics are mainly determined by large variations in irradiance, temperature, nutrients, and river runoff (Hitchcock and Smayda 1977, Cloern 1987, Alpine and Cloern 1988, Underwood and Kromkamp 1999, Eyre and Balls 1999). In general, tropical estuaries are characterized by higher temperature and irradiance levels year round, and larger variations in river runoff, than temperate estuaries (Nittrouer et al. 1995, Eyre and Balls 1999). These characteristics lead to high primary productivity rates, with some tropical estuaries being among the most productive aquatic systems globally (Cloern et al. 2013). Despite the importance of tropical estuaries in terms of primary production, current information on the structure, abundance and ecology of the phytoplankton and the factors driving its dynamics in such systems is scarce compared to that for temperate ones (Costa et al. 2009, Cloern and Jassby 2010, Cloern et al. 2013).

Microplankton are a critical key in the pelagic community of aquatic ecosystems. Microphotoautotrophic primary production is readily transferred to large zooplankton and small fishes (Azam et al. 1983, Costalago et al. 2012), whereas microzooplankton not only graze on microphytoplankton and autotrophic and heterotrophic nanoplankton, but also act as prey to higher trophic levels (Azam et al. 1983, Di Poi et al. 2013). Therefore, microplankton integrate the matter and energy flowing through different pathways along the microbial food web and channels it to higher trophic levels (Calbet and Landry 2004, Calbet and Saiz 2005). Microplankton in estuaries also play a major role in benthic-pelagic coupling through consumption by bivalves and other benthic filter feeders (Officer et al. 1982, Werner and Hollibaugh 1993, Greene et al. 2011). In addition, benthic diatoms are frequently resuspended 
to the water column, thus contributing to pelagic primary production (Shaffer and Sullivan 1988, Jonge and Beusekom 1995). The increasing human pressure on tropical estuaries over the last decades has had a major impact on their ecology and their ecosystem services (Bianchi 2007, Barbier et al. 2011, Blaber 2013). Changes in environmental variables due to climate change can also affect phytoplankton communities' structure, zooplankton and fish (Vezzulli et al. 2012). Therefore, understanding seasonal variability and which variables influence the structure and function of microplankton is necessary to be able to predict their future response to anthropogenic and climate changes.

The Gulf of Nicoya, located in the Pacific Coast of Costa Rica, is a highly productive estuarine system (Peterson 1960, Gocke et al. 2001, Cloern et al. 2013) supporting important fisheries, particularly in its inner basin (Vargas 1995, Palter et al. 2007). The hydrographic structure and dynamics of the water column in the inner basin of Nicoya Gulf are strongly influenced by seasonal changes in freshwater flow from the Tempisque River (Lizano 1998, Brenes et al. 2001). These seasonal changes in the river runoff are likely to affect the biological community and the flow of matter and energy in the estuarine ecosystem, including water column productivity and phytoplankton taxonomic composition (Sin et al. 2000, Smayda and Reynolds 2003, Costa et al. 2009, Cloern et al. 2013). Changes in the species that dominate the estuary can lead to harmful algal blooms, such as those already reported in the Gulf of Nicoya (Hargraves and Vízquez 1995, Vargas and Freer 2004, Vargas et al. 2008). In the inner basin of Nicoya Gulf, important changes in inorganic nutrients, oxygen, and chl $a$ concentrations have been reported along the river - sea gradient (Kress et al. 2002, Palter et al. 2007). However, similar to other tropical estuaries, there is scarce information on how the different components of the planktonic community respond to seasonal changes in the environmental conditions (Cloern and Jassby 2010, Cloern et al. 2013). Previous studies in the Gulf of Nicoya provided a general taxonomic description of the microphytoplankton community, showing that the community composition differs from that in other areas of the Pacific Central America coast (Hargraves and Víquez 1981, 1985). Changes in phytoplankton taxonomic composition together with the physicochemical properties and chl $a$ concentrations, have been studied in only a single 
point in the inner gulf (Brugnoli-Olivera and Morales-Ramírez (1999, 2001, and 2008).

131 Therefore, as yet, no single study has considered all the environmental variables, phytoplankton

132 abundance and taxonomy during the two tropical seasons along the inner Gulf, and therefore established the possible drivers of the tropical estuarine phytoplankton composition. In addition, understanding spatial and seasonal dynamics of microplankton in tropical and subtropical estuaries is essential to evaluate the contribution of estuaries to global biogeochemical cycles; however, such studies are largely biased toward temperate European and North American estuaries, with warmer estuaries being largely under-represented (Cloern and Jassby 2010, Cloern et al. 2013).

Here we study the abundance and composition of the microplankton community in the inner part of a tropical estuary, the Gulf of Nicoya, where changes in the main river runoff was expected to be the greatest influence. We hypothesized that there is a seasonal shift of the microplankton community and question whether it fits an ecotone or ecocline model along the river-sea gradient. We examine patterns of variability and potential environmental factors influencing microplankton abundance and species composition in tropical estuaries as model of gradient aquatic ecosystems. The results provide new insight into the relationship between species and environmental variables in tropical estuaries in order to identify management strategies that protect these important coastal ecosystems.

\section{Material and methods}

\subsection{Study area}

The Gulf of Nicoya is a mid-sized tropical estuary located in the northwest Pacific coast of Costa Rica $\left(10^{\circ} \mathrm{N} 85^{\circ} \mathrm{W}\right)$ (Fig 1). The estuary is $80 \mathrm{~km}$ long from the mouth of the Tempisque River to the Pacific Ocean and $50 \mathrm{~km}$ wide at its southernmost extension, having a total surface area of $1543 \mathrm{~km}^{2}$. Based on its bathymetry, the gulf can be divided into two regions: the inner gulf, from the river mouth to the Puntarenas Channel, with a maximum water depth of $\sim 20 \mathrm{~m}$, and the external gulf, with depths down to $\sim 200 \mathrm{~m}$ (Fig. 1). Sand and rocky cliffs border the external gulf, whereas mangroves border the inner gulf (Voorhis et al. 1983, Palter et al. 2007). 
Tides are semidiurnal with mean amplitude of $2.28 \mathrm{~m}$ (Lizano 2006) and the gulf is classified as a mesotidal estuary (Monbet 1992). Freshwater inputs from the Tempisque River produce intense salinity gradients in the inner gulf; mean discharge rates range between 333.3 and 157.9 $\mathrm{m}^{3} \mathrm{~s}^{-1}$ during the rainy (May - November) and dry seasons (December - April), respectively (Kress et al. 2002). The mean values of the sampled months were inside normal historical conditions.

\subsection{Sampling and sample processing}

Samples were collected in late July 2011, during the rainy season, and in mid April 2012, during the dry season. Five sampling stations were selected along the inner gulf, starting from the mouth of the estuary (Station 1) to the middle of the channel, between Isla Caballo and the eastern coast (Station 5) (Fig. 1). Both sampling cruises started from Station 1 at high tide and followed the ebb tide flow to avoid biases due to the tidal cycle. Temperature, salinity and turbidity were measured along the entire water column using a YSI 6600 multiparameter sonde. Quantum Scalar Irradiance (QSI) was measured with a LI-COR 250A radiometer equipped with a LI-193 Underwater Spherical Quantum Photosynthetic Active Radiation (PAR) sensor. The depth of the euphotic layer ( $1 \%$ of incident light) and the coefficient of light extinction were calculated from the model of Beer-Lambert.

Water samples were collected with a 4.2 L Van Dorn bottle from the surface layer (0 - 1 $m$ depth) and one meter under the halocline in the rainy season or one meter above the bottom in the dry season, when the water column was mixed. Water samples for chl $a$ analysis and nutrients, ammonium $\left(\mathrm{NH}_{4}{ }^{+}\right)$, nitrite $\left(\mathrm{NO}_{2}{ }^{-}\right)$, nitrate $\left(\mathrm{NO}_{3}{ }^{-}\right)$, silicate $\left(\mathrm{SiO}_{4}{ }^{4-}\right)$ and phosphate $\left(\mathrm{PO}_{4}{ }^{3-}\right.$ ) were stored in polyethylene bottles until further processing at the Punta Morales Marine Station (National University of Costa Rica). For chl $a$ extraction, a known volume of water was filtered through Whatman GF/F filters. Filters were placed in tubes with $100 \%$ methanol (buffered with $\mathrm{MgCO}_{3}$ ) to extract pigments overnight at $4^{\circ} \mathrm{C}$ in darkness. Tubes were then centrifuged and the absorption spectrum $(400-800 \mathrm{~nm})$ of the extract was measured on a 
Ritchie (2008). Nutrient samples were filtered through Whatman GF/F ( $0.7 \mu \mathrm{m}$ pore size) filters

187 and stored frozen at $-20^{\circ} \mathrm{C}$ until analysed. Nutrient concentration was determined on a ZUZI 4211/50 spectrophotometer following standard protocols: nitrite and nitrate (Garcia-Robledo et al. 2014), ammonium (Bower and Holm-Hansen 1980), and silicate and phosphate (Grasshoff 1999). For the determination of CDOM, samples were filtered in situ through double filters, a Whatman GF/F pre-filter and a Millipore $0.2 \mu \mathrm{m}$ pore size cellulose acetate filter, in combusted glass vials. Absorbance was measured on a Shimadzu UV - 1700 spectrophotometer with a 10 $\mathrm{cm}$ quartz cell in the spectral range $400-700 \mathrm{~nm}$. The absorption at $440 \mathrm{~nm}$ was used as a measure of CDOM concentration and the spectral region $400-440 \mathrm{~nm}$ for the calculation of the CDOM slope. All samples were kept on ice during sampling, for no more than six hours until arrived to the lab.

To ensure the presence of large cells and minimize the sampling bias, water samples (4 to 2011 , with a spatial resolution of $4 \times 4 \mathrm{~km}$, to produce climatological seasonal images. This allows us to assess, which are the regional conditions and evaluate if the sampling period corresponded to standard conditions of the Gulf. 

server (http://oceancolor.gsfc.nasa.gov) and processed using Matlab toolbox hdfreader and projected to Mercator scale by the toolbox M_Map written by Pawlowicz (http://www.eos.ubc.ca/ rich/map.html).

217

\subsection{Statistical analysis}

A Bray-Curtis similarity matrix of square root transformed phytoplankton abundance was first calculated, followed by a cluster analysis based on group averages. Significant groups at a $\mathrm{p}<0.05$ level were determined by the SIMPROF routine. Then a non-metric multidimensional scaling (nMDS) ordination plot was constructed using the same matrix. SIMPROF groups were indicated on the same plot. Spearman correlations between the environmental variables and the axes of the phytoplankton community ordination plot were drawn. Multivariate analyses were performed using the statistical package PRIMER 6 (Plymouth Marine Laboratory, UK). index was calculated according to Shannon and Weaver (1963) using the following equation: $H=-\sum_{i=1}^{S} p_{i} \operatorname{Ln}\left(p_{i}\right)$. Diversity values for the groups obtained from the SIMPROF routine during cluster analysis are also shown. stations in both seasons. Abundance data was first transformed to microplankton biovolume from mean size of most abundant taxa (Hillebrand et al., 1999, López-Fuerte and SiqueirosBeltrones 2006) and then to biomass ( $\mu \mathrm{g} \mathrm{C} \mathrm{L} \mathrm{L}^{-1}$ ) using conversion factors (Eppley et al. 1970, Leblanc et al. 2012).

\subsection{Characterization of study area by remote sensing}


and averaged for the dry and the rainy seasons were processed to obtain the typical conditions of

241 the Gulf with respect to the rest of the Pacific coast of Costa Rica (Fig. 2). During the rainy season, the inner gulf is warmer than adjacent oceanic and coastal areas (Fig. 2a), whereas during the dry season it tends to be cooler than the southwest coast of Costa Rica (Fig. 2b). Waters inside the estuary have a difference of $\sim 1.5^{\circ} \mathrm{C}$ between seasons. $\mathrm{Chl} a$ concentration in the Gulf of Nicoya was about five times higher than in any adjacent coastal and oceanic areas at all times despite evident differences in SST between seasons (Fig. 2c, d). Mean chl $a$ values in the rainy season reached $\sim 18 \mathrm{mg} \mathrm{m}^{-3}$. These images confirm the high and constant productivity of this tropical estuary compared with the rest of the Costa Rican coast.

\subsection{Environmental variables in the inner Gulf of Nicoya}

A clear salinity gradient was present along the studied transect during both seasons, being slightly steeper during the rainy season (Fig. 3a, b). In addition, during the rainy season, a halocline developed between 1-2 m depth at all sampling stations, being more pronounced in the middle of the estuary (Fig. 3a). No halocline was observed during the dry season (Fig. 3b). The information from rainfall stations in the basin of the Tempisque river indicate that rainfall during the sampling months was $\sim 200 \mathrm{~mm}$ in rainy season, $\sim 100 \mathrm{~mm}$ in dry season (INM 2009). These values are within the normal range in the area. Temperature patterns were similar in both seasons, reaching maximum values at the surface of intermediate stations in the rainy season, where higher thermal stratification was observed (Fig 3c). strongly mixed water column in the dry season was more turbid throughout the entire estuary compared to the rainy season, especially in subsurface layers, with the highest values being observed in Station 1 (Fig. 4). In accordance to this, the depth of the euphotic layer (1\% of incident light) increased from Station 1 ( $\sim 1 \mathrm{~m}$ in both seasons) to Station 5 (12 $\mathrm{m}$ and $4.5 \mathrm{~m}$, in rainy and dry seasons, respectively), being deeper than the halocline during the stratified rainy season (Fig. 3a). Whereas turbidity is the measurement of attenuation of light due to particulate 
matter, CDOM is also responsible of the depth of the euphotic layer because reduces the light intensity and absorbs from ultraviolet to blue lights. According to turbidity, CDOM decreased from the riverine stations seawards, but interesting, was higher during the rainy season than in the dry season (Fig. 4).

Strong nutrient concentration gradients existed for $\mathrm{NO}_{3}{ }^{-}, \mathrm{PO}_{4}{ }^{3-}$ and $\mathrm{SiO}_{4}{ }^{4-}$ along the estuary in both seasons (Fig. 5). Concentration of $\mathrm{NO}_{3}{ }^{-}$decreased from $18.5 \mu \mathrm{M}$ (rainy) and $33.2 \mu \mathrm{M}$ (dry) at the estuary head to less than $7.4 \mu \mathrm{M}$ on average at the marine end. No significant differences were found between surface and bottom water samples, especially in the dry season; however, a depletion of surface $\mathrm{NO}_{3}{ }^{-}$at the marine Stations 4 and 5 in the rainy season was evident. The $\mathrm{NO}_{3}{ }^{-}$versus salinity plot shows a non-conservative decrease of $\mathrm{NO}_{3}{ }^{-}$ from Station 2 in the dry season and from Station 3 in the rainy season. $\mathrm{PO}_{4}{ }^{3-}$ concentration showed a similar pattern to $\mathrm{NO}_{3}{ }^{-}$, decreasing from $5.6 \mu \mathrm{M}$ (rainy) and $4.8 \mu \mathrm{M}$ (dry) at the river to $1.5 \mu \mathrm{M}$ at Station 5. Differences with depth were also generally small, with the exception of Station 1 during the rainy season. $\mathrm{PO}_{4}{ }^{3-}$ concentrations remained constant during the dry season up to Station 2 over a large range of salinities ( 10 to $>30)$, decreasing strongly and nonconservatively towards the sea. However, $\mathrm{PO}_{4}{ }^{3-}$ changes with salinity were more conservative in the rainy station. $\mathrm{NO}_{2}{ }^{-}$concentrations changed non-conservatively along the estuary with highest values $(\sim 3 \mu \mathrm{M})$ in the middle of estuary at intermediate salinities in both seasons. $\mathrm{SiO}_{4}{ }^{4-}$ concentrations were very high $(>1000 \mu \mathrm{M})$ near the river, decreasing conservatively according to salinity along the estuary to concentrations lower than $200 \mu \mathrm{M}$ at Station $5 . \mathrm{NH}_{4}{ }^{+}$ concentrations were generally low $(\sim 2 \mu \mathrm{M})$ in both seasons, especially for the dry season. $\mathrm{NH}_{4}{ }^{+}$ concentrations in bottom waters decreased from the estuary head to the estuary mouth during the rainy season and the inverse trend occurred during the dry season. Although no clear spatial trend was observed for surface $\mathrm{NH}_{4}^{+}$concentrations.

Overall, when considering the seasons, concentrations of $\mathrm{NO}_{\mathrm{x}}$ and $\mathrm{PO}_{4}{ }^{3-}$ were higher during the dry season, whereas the opposite was true for $\mathrm{SiO}_{4}{ }^{4-}$.

\subsection{Chl a and microplankton abundance}


the rainy season, chl $a$ concentrations in the bottom layer was nearly constant $\left(\approx 5 \mathrm{mg} \mathrm{m}^{-3}\right)$, whereas in the surface layer it was highest at the intermediate stations $\left(\sim 20 \mathrm{mg} \mathrm{m}^{-3}\right)$ decreasing toward the sea. In the dry season, chl $a$ concentrations in the surface and bottom layers showed inverse patterns along the estuary; concentrations increased from the river toward the estuary mouth in the surface layer, whereas in the bottom water, chl $a$ maxima occurred in the shallower riverine and intermediate stations (Stations 1 - 3). the rainy season, abundance in both surface and bottom layers increased from river to sea, following the opposite trend as chl $a$ from the middle of the estuary toward the sea (Fig. 6). In contrast, during the dry season, total abundance followed the trend observed for $\operatorname{chl} a$; abundance in the bottom layer decreased from the estuary head to the estuary mouth, and increased in the surface. Disagreements between chl $a$ and microphytoplankton abundance trends in the surface during the rainy season are likely due to the lesser abundance of microphytoplankton $(9.4 \%$ of total biomass $)$, compared to the almost double microphytoplankton representation in the dry season (Table 2).

\subsection{Microplankton diversity and taxonomic groups}

In total 146 microplanktonic taxa were identified (>95\% to species level) in the inner basin of the Gulf of Nicoya over the seasons (Online Resource A). Shannon diversity index (H) for microplankton changed between stations and ranged from 1.70 to 2.90 (Table 1). Diversity index values obtained during the rainy season were generally higher than those obtained in the dry season. In the rainy season, diversity index did not show any clear trend along the estuary or with depth; during the dry season, on the other hand, diversity values were generally higher in surface water and towards the marine stations. abundance for centric diatoms and $15 \%$ for pennate diatoms). The second most abundant group was dinoflagellates (7.5-8.5\%). Other groups such as tintinnids, Chlorophyta, ciliates, 
Haptophyta, Cyanobacteria, and Euglenophyta, represented all together less than $3 \%$ of the total abundance (Fig. 7).

Centric diatoms abundance was one order of magnitude higher than that of pennate diatoms in estuary head (898 ind $\mathrm{mL}^{-1}$ and 90 ind $\mathrm{mL}^{-1}$, respectively). The centric diatoms Cerataulina dentata and Thalassiosira spp. were the most abundant taxa during the rainy season and Cyclotella spp. during the dry season. The pennates Thalassionema nitzschioides and Cylindrotheca closterium were the species with the highest abundance during both seasons.

Dinoflagellates were more abundant in the surface layer, increasing toward the sea in both seasons and reaching 165 ind $\mathrm{mL}^{-1}$ in Station 5 during dry season. The heterotrophic Protoperidinium spp. (16\% of dinoflagellates) and autotrophic Prorocentrum minimum (61\% of dinoflagellates) were the most abundant species in rainy and dry season, respectively.

Chlorophytes abundance was low, with the highest abundance observed at the estuary head $\left(5\right.$ ind $\left.\mathrm{mL}^{-1}\right)$. The freshwater genus Scenedesmus spp. was the most abundant genus in both seasons. Tintinnids were patchily present and only in low abundances $\left(>8\right.$ ind $\left.\mathrm{mL}^{-1}\right)$. Codonellopsis spp. was the most abundant genus. From the rest of the groups mentioned above, the most representative were the ciliate Strobilidium spp. $\left(7\right.$ ind $\left.\mathrm{mL}^{-1}\right)$ and flagellate Ebria tripartita $\left(7\right.$ ind $\left.\mathrm{mL}^{-1}\right)$, both during the rainy season (Online Resource B).

\subsection{Microplankton assemblages and their relationship with environmental variables}

The nMDS ordination obtained from the microplankton community data showed a clear spatial gradient on the horizontal axis separating the stations from the estuary head (Station 1) to the estuary mouth (Station 5) (Fig. 8A). On the vertical axis, stations from the rainy and dry seasons were also clearly separated. SIMPROF analysis of the group averages dendogram plot identified five significant groups or assemblages in the microplankton community (DI, DII, RI, RII, RIII). DI includes the surface and bottom samples in Station 1 during dry season. DII consists of the remaining samples along the estuary during dry season. Samples at Station 1 during the rainy season are named RI, whereas RII comprises surface samples at Stations 2 and 3 during the rainy season. Finally, RIII includes the remaining rainy season samples, namely 
surface layer samples at Stations 4 and 5, and bottom layer samples from Station 2 to Station 5 (see Online Resource B for detailed taxonomic composition of groups). According with the geographical separation obtained with the nMDS, the Shannon diversity index showed the lowest $\mathrm{H}$ values in the estuary head groups (DI \& RI) as well as seasonal differences with the highest diversity in the rainy season.

High correlations of environmental variables were found with the axes of the ordination plot. Turbidity, $\mathrm{NO}_{3}{ }^{-}$and $\mathrm{PO}_{4}{ }^{3-}$ concentrations showed high correlation $(\mathrm{p}>0.7)$ with the first axis, the horizontal one, separating the inner most station from outer-marine stations. A lower correlation ( $\mathrm{p}>0.5$ ) was shown by CDOM slope, $\mathrm{CDOM}$ concentration and $\mathrm{SiO}_{4}{ }^{4-}$. With respect to the second axis, which separates samples for rainy and dry seasons, high correlations $(\mathrm{p}>0.5)$ were found with salinity, $\mathrm{SiO}_{4}{ }^{4-}$ and $\mathrm{CDOM}$ (Fig. 8a).

The taxa that showed the highest correlations with the horizontal axis of the ordination plot were Scenedesmus opoliensis associated to riverine waters, especially in the rainy season, and Chaetoceros curvisetus and Cerataulina dentata, which increased toward marine stations in the rainy season. The species that showed the largest variations between seasons, Cyclotella spp., Thalassiosira spp., and Thalassionema nitzschioides, were more representative during the dry season, whereas the opposite was true for Protoperidinium pallidum (Fig. 8b).

\section{Discussion}

\subsection{The importance of the Tempisque River}

The Tempisque River discharges a large volume of fresh and relatively warm water to the inner gulf, approximately 2 times higher in the rainy season than in the dry season (Kress et al. 2002). The seasonal difference in river runoff is a major driver of change in the water column's physical structure of tropical estuaries, with wide implications for phytoplankton abundance and primary production (Ram et al. 2003 Costa et al. 2009, Burford et al. 2012). In the dry season, when the fresh water flow is lower, tidal currents mix the water column (wellmixed estuary phase). In contrast, during the rainy season, tidal mixing was insufficient to fully 
mix the water column, shifting the estuarine physical dynamics to a phase of partially stratified estuary, as found previously here (Brenes et al. 2001, Lizano 2006) and in other tropical estuaries (Eyre 1998, Eyre and Balls 1999, Boonphakdee and Fujiwara 2008).

The Tempisque River discharges a large amount of particulate and dissolved organic and inorganic matter to the estuary. Intense longitudinal gradients of turbidity, CDOM and nutrients were observed from the riverine to the marine end of the inner estuary. Turbidity was highest in the dry season, contrary to what has been observed in other estuaries (Cravo et al. 2006, Lund-Hansen et al. 2010), while CDOM showed the inverse seasonal variation, being higher in the rainy season. CDOM can increase due to the river discharge and resuspension of bottom sediments. Here, the higher values during the rainy season confirm the hypothesis that the influence of the river prevails over the tidal force. Although the total amount of CDOM decreased seawards, the slope of CDOM absorption spectra increased (results not shown) showing a progressive decrease of the more refractory allochthonous component from terrestrial and mangrove origin along the estuary (Stedmon and Markager 2003, Galgani et al. 2011). Higher concentration of CDOM during rainy season has been reported in other subtropical and tropical estuaries as well (Gallegos 2005, Lund-Hansen et al. 2010), although there are reports where no clear seasonal differences were found (Maie et al. 2006). Overall, concentrations of CDOM reported here are higher than those reported in estuaries from different latitudes (LundHansen 2004, Lund-Hansen et al. 2010, Maie et al. 2006). These spatial patterns and their seasonal changes reinforce the importance of the Tempisque River as a source of allochthonous particulate and dissolved matter for the Gulf of Nicoya.

The most abundant inorganic nutrients concentrations, namely $\mathrm{NO}_{3}{ }^{-}, \mathrm{PO}_{4}{ }^{3-}$ and $\mathrm{SiO}_{4}{ }^{4-}$, decreased downstream suggesting that the Tempisque River was an important source of inorganic nutrients in both seasons. $\mathrm{NO}_{3}^{-}$and $\mathrm{PO}_{4}{ }^{3-}$ were lower during the rainy season, suggesting a dilution by precipitation of the last two nutrients. At the same time, rain would increase the $\mathrm{SiO}_{4}{ }^{4-}$ input from stronger runoff effect during the rainy season. However, the range of $\mathrm{NO}_{3}{ }^{-}, \mathrm{PO}_{4}{ }^{3-}$ and $\mathrm{SiO}_{4}{ }^{4-}$ concentrations measured in this study at the most riverine stations 
were higher than concentrations reported previously for the Gulf of Nicoya (Kress et al. 2002, Brugnoli-Olivera and Morales-Ramírez 2008 and Palter et al. 2007) and other tropical estuaries (Rochelle-Newall et al. 2011, Burford et al. 2012, Pamplona et al. 2013). This increase in nutrients concentration could be due to anthropogenic inputs (expansion in agriculture, industrial waste and untreated sewage), affecting the water sources that discharge directly into the Gulf of Nicoya (Bower 2013). The generally low N:P stoichiometric ratio observed in the water column, which decreased from the river $(\sim 6: 1)$ to $(\sim 2: 1)$ seawards, indicate $\mathrm{N}$ limitation, but as concentrations measured were high, it is not relevant. Moreover, concentrations were higher than typical half-saturation constants of nutrient uptake for natural phytoplankton communities and diatom species, meaning that nutrient limitation will be only expected for some species in the surface layer of the outer stations (Fisher et al. 1988).

Silicate was always in stoichiometric excess over $\mathrm{N}$ and $\mathrm{P}$ and conservative with respect to salinity, favouring the observed dominance of diatoms $(88 \%)$ in the microplankton community. Tropical estuaries dominated by diatom communities seem to be a common occurence (Devassy and Goes 1988, Jennerjahn et al. 2004, Madhu et al. 2007, Costa et al. 2009, Canini et al. 2013). Dinoflagellates represented the second most abundant group (8\%) after diatoms as is often found in tropical estuaries (Sidik et al. 2008, Costa et al. 2009, Biswas et al. 2010 Canini et al. 2013). Dinoflagellates were more abundant in the warmest season in a Philippine mangrove estuary (Canini et al. 2013), and they were more abundant as well during the dry season and toward the mouth of the Marapanin tropical estuary in Brazil (Santana et al. 2010). In the Gulf of Nicoya, dinoflagellates abundance generally increased towards marine stations showing higher abundance during the dry season. Many dinoflagellates, including toxic species, have a better ability to obtain nutrients than diatoms under non-Redfield ratios, explaining why diatoms and dinoflagellates follow opposite trends in distribution along the estuary (Glibert et al. 2011). The most abundant specie was Prorocentrum minimum in the surface of the most marine station during the dry season. P. minimum causes harmful algal blooms in many estuaries and coastal environments, including the Pacific coast of Costa Rica, 

et al. 2008).

Other nutrients, $\mathrm{NO}_{3}{ }^{-}, \mathrm{NO}_{2}{ }^{-}$and $\mathrm{PO}_{4}{ }^{3-}$, clearly changed in a non-conservative way with salinity along the estuary. The strong increase in the slope of $\mathrm{NO}_{3}^{-}$from the middle of the estuary most likely indicates a strong increase in $\mathrm{NO}_{3}{ }^{-}$consumption by phytoplankton. At the same time there is a $\mathrm{NO}_{2}{ }^{-}$maximum that, in oxic environments, usually indicates an interrelated mechanism of excess in assimilatory nitrate reduction rate by phytoplankton below the photic zone, and nitrification by bacteria in surface layers (Lomas and Lipschultz 2006). The relationship of $\mathrm{PO}_{4}{ }^{3-}$ versus salinity, which is particularly evident in the dry season, indicates the existence of a source of this nutrient in Station 3, probably due to sewage waters. The combination of a new source of nutrients at this point, together with less turbid waters than in the estuary head, clearly trigger the observed chl $a$ maximums. This study shows an increase in nutrients over those observed in past studies, probably due to an increase in inappropriate agricultural practises, untreated sewage and industrial waste (Bower 2013), highlighting the necessity of biogeochemical studies in tropical estuaries to predict the response of an evident increase in nutrients input.

The changes in turbidity, CDOM and inorganic nutrients along the estuary and between seasons described above confirm the high heterogeneity of this gradient ecosystem, which likely favours the development of different microplankton assemblages along the estuary. Despite differences in the relative contribution of freshwater and marine sources to nutrient budgets (Kress et al. 2002, Palter et al. 2007), the relatively constant input of nutrients from the Tempisque River could explain the continuous high standing stocks of chl $a$. Satellite images show that the Gulf of Nicoya has regularly high chl $a$ values compared to the rest of the Pacific coast of Costa Rica, regardless of season. Our discrete sampling of chl $a$ agreed with the average values from the satellite images for each season, showing that the sampling period represents the typical seasonal conditions in the Gulf. The range of chl $a$ concentrations (2.7 -

$45820 \mathrm{mg} \mathrm{m}^{-3}$ ) measured in our study was similar to those reported previously for the Gulf of 459 Nicoya (Kress et al. 2002, Palter et al. 2007) and other tropical estuaries with diverse nutrient 

concentrations of the annual mean chl $a$ concentrations $\left(0.2-50 \mathrm{mg} \mathrm{m}^{-3}\right)$ of a data set of 84 estuaries worldwide (Cloern and Jassby 2010). In the Gulf of Nicoya, the range of chl $a$ concentration was similar in both seasons, although highest values were found in the surface layer in the rainy period. The pattern and amplitude of seasonal changes in phytoplankton biomass in estuaries seems to be site-dependent. Higher chl $a$ concentrations during the rainy season, or after episodic increased flow events, is a common feature in tropical and subtropical estuaries (Le et al. 2013, Cloern 1991, Adolf et al. 2006, Abreu et al. 2009). The higher phytoplankton biomass during the rainy season has been attributed to higher nutrient inputs and a stronger stratification in the water column due to the increased fluvial discharge (Cloern et al. 2013). Nonetheless, other studies show that high riverine runoff could increase turbidity and decrease water residence time. This could favour a decrease in primary production and the flushing of phytoplankton biomass out of the estuary, resulting in lower chl $a$ concentration (Sin et al. 2000, Ram et al. 2003, Costa et al. 2009, Burford et al. 2012). However, we found that in this middle station as the estuary becomes wider, the current decreases and accumulation of phytoplankton is favoured. Additionally, we found less turbidity during the rainy season, which likely favoured primary production. The presence of a chl $a$ peak in the middle of the inner part of the Gulf of Nicoya, after the salt wedge, is a typical feature of stratified and partially stratified estuaries (Voorhis et al. 1983, Collins and Williams 1981, Humborg et al. 1997,

479 Cloern et al. 2013). This happens because while turbidity decreases along the estuary, inorganic nutrients are still available in high concentrations, stimulating phytoplankton production and growth (Sverdrup 1953).

During the dry season, the higher chl $a$ and microplankton abundance at the bottom layer coincident with turbidity maxima could be explained by a combination of physical accumulation and river-marine inputs of both particles and cells (Lancelot and Muylaert 2011). Except on this occasion, microplankton abundance in the Gulf of Nicoya generally increased towards the sea. 

For example, in the York River estuary, microplankton abundance increased seaward and was correlated with river discharge (Sin et al. 2000), whereas in an Indian tropical estuary, microphytoplankton abundance did not show any clear spatial trend in any season (Madhu et al. 2007). In the Gulf of Nicoya, microplankton abundance along the estuary did not generally coincide with chl $a$ patterns. One explanation for this discrepancy is the fact that phytoplankton biomass in the Gulf was dominated by nanoplankton in both seasons, while estimated microplankton biomass contributed only $9.4 \%$ and $16.8 \%$ of the total in the rainy and dry seasons, respectively (Table 2). Furthermore, direct measurements of chl $a$ concentration in the microplankton fraction did not exceed $6.8 \%$ of total chl $a$ in a parallel size-fractionation study during the same sampling campaign (Soria 2011). In this estuary, we observed that higher river flow supports better nanoplankton populations, which are able to maintain their biomass, even in high flushing conditions, due to the ability of these cells to grow fast (Costa et al. 2009).

\subsection{Ecological drivers of microplankton assemblages}

Taxonomic analysis of microplankton revealed 146 taxa in the Gulf of Nicoya, when

both seasons are considered (Online Resource A), 52 of them being new taxa for the Pacific coast of Costa Rica (Víquez and Hargraves 2009). This is a relatively high number of species compared with the 60 species of diatoms and 6 of dinoflagellates reported in other estuaries on the same Costa Rican coast (Morales-Ramírez 2011). The species richness in the Gulf of Nicoya 2013, Santiago et al. 2010).

The nMDS ordination analysis showed clear changes in the taxonomic composition and relative abundance of different taxa in the microplankton community along the estuary and with seasons. Changes in the phytoplankton community using multivariate techniques have also been

513 observed in other temperate and tropical estuaries (Devassy and Goes 1988, Lassen et al. 2004,

514 Santiago et al. 2010, Matos et al. 2011, Lawrenz et al. 2012, Canini et al. 2013). SIMPROF 
analysis identified five statistically significant groups of microplankton samples, two during the dry season and three during the rainy season. The innermost Station 1, exhibited characteristic associations of microplankton species (DI and RI) for each season, that differed significantly in taxonomy and abundance from the rest of the estuary. Estuaries are a transition zone and can be differentiated into two main types of boundary model: ecotone, when the transition is a narrow ecological zone that separates two relative homogenous zones, and ecocline when the transition is gradual (Atrill and Rundle 2002, Quinlan and Phlips 2007, Muylaert et al. 2009). Most studies using multivariate ordination techniques applied to the phytoplankton community in estuaries clearly separate a riverine assemblage from the rest of the estuarine community (Quinlan and Philips 2007, Matos et al. 2011, Canini et al. 2013). Our results seem to support both: the "ecotone model" since the community in the estuary head was clearly separated in the nMDS ordination plot from the rest, and the "ecocline model" since microplankton assemblages presented higher similarities for the rest of the estuary.

DI and RI consist of mainly estuarine-marine microplankton species that reach Station 1 with the incoming bottom marine current (Cyclotella spp., Thalassiosira spp., Paralia sulcata, Thalassionema nitzschioides) and are mixed with some riverine species (e.g. Scenedesmus opoliensis), especially in the rainy season. The occurrence of freshwater species in the Gulf of Nicoya was low compared to others estuaries (Costa et al. 2009). Major differences between DI and RI (i.e. between seasons) were mainly due to the higher abundance of centric and pennate diatoms during the dry season (Santiago et al. 2010). Pennate and centric diatoms were more abundant in the dry season, particularly in the bottom water, where turbidity was higher. The benthic species (i.e. T. nitzschioides) found in the most turbid waters confirmed the effect of hydrodynamic driven accumulation of resuspended sediment and cells in the estuary head due to inward bottom tidal currents.

During the dry season, the rest of the estuary (DII) was characterised by the marine species Cyclotella spp., Thalassiosira spp, and T. nitzschioides. The higher mixing of the water column in the estuary in the dry season (Brenes et al. 2001) was likely the main reason for this uniformity in the microplankton community along the estuary. In contrast, during the rainy 
season, the more complex hydrographic conditions characterised by a stratification in the water

544 column supported a higher degree of habitat heterogeneity that explains the existence of two 545 microplanktonic assemblages in the rest of the estuary (RII and RIII). RII included only surface 546 samples from Stations 2 and 3, characterised by intermediate salinities (between 16 and 22). 547 The microplankton assemblage of RII coincides with the stations where the chl $a$ maximum was found in the rainy season (Station 3), with most of this chl a coming from autotrophic nanoplankton. Nanoplankton and picoplankton form the basic food source of the heterotrophic dinoflagellate Protoperidinium pallidum, and the oligotrichous ciliate Strobilidium $s p$. (Rassoulzadegan et al. 1988), which, together with the centric diatom Ceratulina dentata, characterised the microplankton community of RII. Finally, RIII, which included samples from the bottom water in Stations 2 and 3 and from both depths in Station 4 and 5, was characterised by the most typically marine species. Centric diatom abundance increased towards the sea because brackish marine water mixes continuously with the overlaying fresher water due to the incoming tidal and residual currents. This mixing seeds the surface layer of the estuary head with marine phytoplanktonic cells where, even with less nutrient, the occurrence of a mixed layer shallower than the photic layer favours diatom growth (Alpine and Cloern 1988). higher during the monsoon period and increasing towards the sea (Jalal et al. 2011, Canini et al. 2013). This spatial pattern agrees with the higher species richness at high salinity of the Remane diagram (Attrill and Rundle 2002) was also observed for the Gulf of Nicoya. We found higher diversity during the rainy season and in the more marine samples (RII and RIII) and in particular in Station 3 which coincides with the chl a maximum. Following the same predictions of the Rename diagram with a minimum in diversity expected at a salinity of about 7, the estuary head groups DI and RI at salinities $<12$ and $<8$ in the rainy and dry seasons respectively presented the lowest diversity. However, it should be noted that despite the high number of taxa we observed, diversity values in the inner Gulf of Nicoya are generally low compared to other tropical estuaries (Maurer and Vargas 1984). 
As we have seen so far, the drivers that control primary producers in tropical estuaries

571 do not follow a simple model. Microplankton community composition in tropical estuaries has

572 been shown to change in response to different abiotic variables such as freshwater flow (Jalal et 573 al. 2011); total suspended solid, salinity and nitrate concentration (Canini et al. 2013); salinity, 574 light and nutrients (Lassen et al. 2004); salinity, light, temperature and nutrients (Quinlan and 575 Phlips 2007); and heavy metal concentrations (Rochelle-Newall et al. 2011). In our area, the correlation between the axes of the nMDS ordination plot with the environmental variables

577 helps to identify which ones better explain the observed group ordination. In the Gulf of Nicoya, nutrients concentration, turbidity, and CDOM were correlated with the first axis separating the riverine (DI and RI) and more marine communities (DII, RII and RIII). The vertical axis separated samples from the dry and rainy seasons and was mainly correlated with salinity, CDOM, silicate and ammonium. Therefore, this study and the scarce available literature linking phytoplankton community composition to changes in environmental variables in tropical estuaries reinforce the importance of changes in freshwater flow, both spatially and seasonally for the phytoplankton community (Lancelot and Muylaert 2011, Cloern et al. 2013). These changes in freshwater flow affect a number of physical and physicochemical variables, like water column stability, residence time, salinity, turbidity, nutrient availability etc., which in turn can promote or suppress biomass and production of specific phytoplanktonic groups (Sin et al. 2000, Cloern et al. 2013).

\section{Conclusion}

Our results confirmed both the seasonal shift of microphytoplankton communities and the existence of a strong riverine-marine gradient. Different microplankton assemblages appear to be driven by seasonal river runoff changes, with specific taxa characterizing each group. While assemblages transitions in the estuary head fit with an ecotone model, these shift to an ecocline model for the rest of the estuary. Our analysis showed that the main ecological driver of microplankton abundance and composition was the light availability (turbidity). Diatoms,

597 followed by dinoflagellates, dominated microplankton species composition, of which 52 are 
new citations for the Pacific coast of Costa Rica. The most abundant dinoflagellate was the toxic Prorocentrum minimum. The present study increases our understanding of microphytoplankton interactions in tropical estuaries and contributes an important dataset that will aid predictions of the anthropogenic effects on these little studied but very productive tropical ecosystems.

\section{Acknowledgements}

The study was funded by projects C/023621/09, D/031020/10 and A1/037457/11 from Spanish Agency for International Development and Cooperation (AECID); project CTM201343857-R supported by the Spanish Ministry of Economy and Competitiveness, and project 808B3-127 at the University of Costa Rica (UCR). We would like to thank all colleagues and the staff from UCA and CIMAR - UCR that contributed to the realization of this study for their personal and logistic support. Also I thank Dr. Alex Poulton, Dr. E. Elena Garcia-Martin and the "Kaiser Lab group" for their comments on this manuscript.

\section{References}

Abreu PC, Bergesch M, Proença LA, Garcia CAE, Odebrecht C (2010) Short- and Long-Term Chlorophyll a Variability in the Shallow Microtidal Patos Lagoon Estuary, Southern Brazil. Estuar Coast 33:554-569

Adolf JE, Yeager CL, Miller WD, Mallonee ME, Harding Jr LW (2006) Environmental forcing of phytoplankton floral composition, biomass, and primary productivity in Chesapeake Bay, USA. Estuar Coast Shelf Sci 67:108-122

Alpine AE, Cloern JE (1988) Phytoplankton growth-rates in a light-limited environment, San Francisco Bay. Mar Ecol Prog Ser 44:167-173 doi:10.3354/meps044167

Attrill MJ, Rundle SD (2002) Ecotone or Ecocline: Ecological Boundaries in Estuaries. Estuar Coast Shelf Sci 55:929-936 doi:10.1006/ecss.2002.1036

Azam F, Fenchel T, Field JG, Gray JS, Meyerreil LA, Thingstad F (1983) The ecological role of water-column microbes in the sea. Mar Ecol Prog Ser 10:257-263 doi:10.3354/meps010257

Barbier EB, Hacker SD, Kennedy C, Koch EW, Stier AC, Silliman BR (2011) The value of estuarine and coastal ecosystem services. Ecol Monogr 81:169-193

Bianchi TS (2007) Biogeochemistry of Estuaries. Oxford University Press, New York

Biswas H, Dey M, Ganguly D, De TK, Ghosh S, Jana TK (2010) Comparative analysis of phytoplankton composition and abundance over a two-decade period at the land-ocean boundary of a tropical mangrove ecosystem. Estuar Coast 33:384-394

Blaber SJM (2013) Fishes and fisheries in tropical estuaries: The last 10 years. Estuar Coast Shelf Sci 135:57-65

Boonphakdee T FT (2008) Temporal Variability of Nutrient Budgets in a Tropical River Estuary: the Bangpakong River Estuary, Thailand. Environ Asia 1:7-21 
Bower CE, Holm-Hansen T (1980) A salicylate-hypochlorite method for determining ammonia in seawater. Can J Fish Aquat Sci 37:794-798

Bower KM (2013) Water supply and sanitation of Costa Rica. Environ Earth Sci 71:107-123 doi:10.1007/s12665-013-2416-X

Brenes CL, León S, Chaves J (2001) Variación de las propiedades termohalinas en el Golfo de Nicoya, Costa Rica. Rev Biol Trop 49:145-152

Brugnoli-Olivera E, Morales-Ramírez A (1999) Parámetros fisico-químicos de la columna de agua en la zona de Punta Morales, Golfo de Nicoya, durante un evento El Niño. Tópicos en Meteorologia y Oceanografía 6:52-57

Brugnoli-Olivera E, Morales-Ramírez A (2001) La comunidad fitoplanctónica de Punta Morales, Golfo de Nicoya, Costa Rica. Rev Biol Mar Oceanogr 49:11-17

Brugnoli-Olivera E, Morales-Ramírez A (2008) Trophic planktonic dynamics in a tropical estuary, Gulf of Nicoya, Pacific coast of Costa Rica during El Niño 1997 event. Rev Biol Mar Oceanogr 43:75-89

Burford MA, Webster IT, Revill AT, Kenyon RA, Whittle M, Curwen G (2012) Controls on phytoplankton productivity in a wet-dry tropical estuary. Estuar Coast Shelf Sci 113:141-151

Calbet A, Landry MR (2004) Phytoplankton Growth, Microzooplankton Grazing, and Carbon Cycling in Marine Systems. Limnol Oceanogr 49:51-57 doi:10.2307/3597609

Calbet A, Saiz E (2005) The ciliate-copepod link in marine ecosystems. Aquat Microb Ecol 38:157-167 doi:10.3354/ame038157

Cloern JE (1987) turbidity as a control on phytoplankton biomass and productivity in estuaries. Cont Shelf Res 7:1367-1381 doi:10.1016/0278-4343(87)90042-2

Cloern JE, Foster SQ, Kleckner AE (2013) Review: phytoplankton primary production in the world's estuarine-coastal ecosystems. Biogeosci Disc 10:17725-17783 doi:10.5194/bgd10-17725-2013

Cloern JE, Jassby AD (2010) Patterns and Scales of Phytoplankton Variability in EstuarineCoastal Ecosystems. Estuar Coast 33:230-241 doi:10.1007/s12237-009-9195-3

Collins NR, Williams R (1981) Zooplankton of the Bristol Channel and Severn Estuary. The distribution of four copepods in relation to salinity. Mar Biol 64:273-283

Costa LS, Huszar VLM, Ovalle AR (2009) Phytoplankton Functional Groups in a Tropical Estuary: Hydrological Control and Nutrient Limitation. Estuar Coast 32:508-521 doi:10.1007/s 12237-009-9142-3

Costalago D, Navarro J, Álvarez-Calleja I, Palomera I (2012) Ontogenetic and seasonal changes in the feeding habits and trophic levels of two small pelagic fish species. Mar Ecol Prog Ser 460:169-181 doi:10.3354/meps09751

Cravo A, Madureira M, Felícia H, Rita F, Bebianno MJ (2006) Impact of outflow from the Guadiana River on the distribution of suspended particulate matter and nutrients in the adjacent coastal zone. Estuar Coast Shelf Sci 70:63-75 doi:10.1016/j.ecss.2006.05.034

Cupp EE (1943) Marine plankton diatoms of the west coast of North America. Scripps Institution Bulletin $51 \mathrm{D}$

Devassy VP, Goes JI (1988) Phytoplankton community structure and succession in a tropical estuarine complex (central west coast of India). Estuar Coast Shelf Sci 27:671-685

Di Poi E, Blason C, Corinaldesi C, Danovaro R, Malisana E, Fonda-Umani S (2013) Structure and interactions within the pelagic microbial food web (from viruses to microplankton) across environmental gradients in the Mediterranean Sea. Glob Biogeochem Cycles 27:1034-1045 doi:10.1002/2013gb004589

Dodge JD (1985) Atlas of dinoflagellates: a scanning electron microscope survey. Farrand Press, London

Eppley RW, Reid FMH, Strickland JDH (1970) Estimates of phytoplankton crop size, growth rate, and primary production. Bulletin of the Scripps Institution of Oceanography 17:3342

Eyre B (1998) Transport, retention and transformation of material in Australian estuaries. Estuaries 21:540-551 doi:10.2307/1353293 
Eyre B, Balls P (1999) A comparative study of nutrient behavior along the salinity gradient of tropical and temperate estuaries. Estuaries 22:313-326

Fisher TR, Harding Jr LW, Stanley DW, Ward LG (1988) Phytoplankton, nutrients, and turbidity in the Chesapeake, Delaware, and Hudson estuaries. Estuar Coast Shelf Sci 27:61-93

Galgani L et al. (2011) Assessing the optical changes in dissolved organic matter in humic lakes by spectral slope distributions. J Photochem Photobiol B: Biol 102:132-139

Gallegos CL (2005) Optical water quality of a blackwater river estuary: the Lower St. Johns River, Florida, USA. Estuar Coast Shelf Sci 63:57-72 doi:10.1016/j.ecss.2004.10.010

García-Robledo E, Corzo A, Papaspyrou S (2014) A fast and direct spectrophotometric method for the sequential determination of nitrate and nitrite at low concentrations in small volumes. Mar Chem 162:30-36 doi:http://dx.doi.org/10.1016/j.marchem.2014.03.002

Glibert P, Burkholder J (2011) Harmful algal blooms and eutrophication: "strategies" for nutrient uptake and growth outside the Redfield comfort zone. Chin J Oceanol Limnol 29:724-738 doi:10.1007/s00343-011-0502-z

Gocke K, Cortes J, Murillo MM (2001) The annual cycle of primary productivity in a tropical estuary: The inner regions of the Golfo de Nicoya, Costa Rica. Rev Biol Trop 49:289306

Grasshoff K, Kremling, K. Ehrhardt, M. (2007) Frontmatter, in Methods of Seawater Analysis., Third Edition edn. Wiley-VCH Verlag GmbH, Weinheim, Germany. doi:10.1002/9783527613984.fmatter

Greene VE, Sullivan LJ, Thompson JK, Kimmerer WJ (2011) Grazing impact of the invasive clam Corbula amurensis on the microplankton assemblage of the northern San Francisco Estuary. Mar Ecol Prog Ser 431:183-193 doi:10.3354/meps09099

Hargraves PE, Viquez R (1985) Spatial and temporal distribution of phytoplankton in the Gulf of Nicoya, Costa Rica. Bull Mar Sci 37:577-585

Hargraves PE, Víquez R (1981) The dinoflagellate red tide in Golfo de Nicoya, Costa Rica. Rev Biol Trop 29:31-38

Heil CA, Glibert PM, Fan C (2005) Prorocentrum minimum (Pavillard) Schiller. Harmful Algae 4:449-470 doi:10.1016/j.hal.2004.08.003

Hitchcock GL, Smayda TJ (1977) The importance of light in the initiation of the 1972-1973 winter-spring diatom bloom in Narragansett Bay. Limnol Oceanogr 22:126-131

Hoppenrath ME, M. Debres, G. (2009) Marine Phytoplankton. Selected microphytoplankton species from the North Sea around Helgoland and Sylt., vol 49. Kleine SenckenbergReihe, Germany

Humborg C, Ittekkot V, Cociasu A, Bodungen Bv (1997) Effect of Danube River dam on Black Sea biogeochemistry and ecosystem structure. Nature 386:385-388

Hustedt F (1930) Die Kieselalgen Deutschlands, Osterreichs und der Schweiz. . In: Kryptogamen-Flora yon Deutschland, Österreichs und der Schweiz, vol 7.

Instituto Meteorológico Nacional. (2009). http://www.imn.ac.cr/boletin_meteo/historial boletines.html. Accessed 22 May 2015

Jalal KCA, Azfar BMA, John BA, Kamaruzzaman YB (2011) Spatial variation and community composition of phytoplankton along the pahang estuary, Malaysia. Asian J Biol Sci 4:468-476

Jennerjahn TC et al. (2004) Biogeochemistry of a tropical river affected by human activities in its catchment: Brantas River estuary and coastal waters of Madura Strait, Java, Indonesia. Estuar Coast Shelf Sci 60:503-514 doi:http://dx.doi.org/10.1016/j.ecss.2004.02.008

Jonge VNd, Beusekom JEEv (1995) Wind-and Tide-Induced Resuspension of Sediment and Microphytobenthos from Tidal Flats in the Ems Estuary. Limnol Oceanogr 40:766-778 doi:10.2307/2838311

Kress N, Coto SL, Brenes CL, Brenner S, Arroyo G (2002) Horizontal transport and seasonal distribution of nutrients, dissolved oxygen and chlorophyll-a in the Gulf of Nicoya, Costa Rica: A tropical estuary. Cont Shelf Res 22:51-66 
Lancelot C, Muylaert K (2011) Trends in Estuarine Phytoplankton Ecology.:5-15 doi:10.1016/b978-0-12-374711-2.00703-8

Larink O, Westheide W (2006) Coastal Plankton. Photo guide for European Seas:143

Lassen MF, Bramm ME, Richardson K, Yusoff F, Shariff M (2004) Phytoplankton community composition and size distribution in the Langat River estuary, Malaysia. Estuaries 27:716-727

Lawrenz E, Smith EM, Richardson TL (2012) Spectral Irradiance, Phytoplankton Community Composition and Primary Productivity in a Salt Marsh Estuary, North Inlet, South Carolina, USA. Estuar Coast 36:347-364 doi:10.1007/s12237-012-9567-y

Le C, Hu C, English D, Cannizzaro J, Kovach C (2013) Climate-driven chlorophyll-a changes in a turbid estuary: Observations from satellites and implications for management. Remote Sens Environ 130:11-24 doi:10.1016/j.rse.2012.11.011

Leblanc K et al. (2012) A global diatom database-abundance, biovolume and biomass in the world ocean. Earth Syst Sci Data 4:149-165

Lebour MV (1930) The Planktonic Diatoms of Northern Seas. Ray Society, London

Lizano OG (1998) Dinámica de las aguas en la parte interna del Golfo de Nicoya ante altas descargas del Río Tempisque. Rev Biol Trop 46:11-20

Lizano OG (2006) Algunas características de las mareas en la costa Pacífica y Caribe de Centroamérica. Ciencia y Tecnología 24:51-64

Lomas MW, Lipschultz F (2006) Forming the primary nitrite maximum: Nitrifiers or phytoplankton? Limnol Oceanogr 51:2453-2467

López-Fuerte FO, Siqueiros-Beltrones DA (2006) Biovolumen ponderado:índice para estimar la contribución de especies en asociaciones de diatomeas bentónicas. Hidrobiológica 17:83-86

Lund JWG, Kipling C, Le Cren ED (1958) The inverted microscope method of estimating algal numbers and the statistical basis of estimations by counting. Hydrobiologia 11:143-170

Lund-Hansen LC (2004) Diffuse attenuation coefficients Kd(PAR) at the estuarine North SeaBaltic Sea transition: Time-series, partitioning, absorption, and scattering. Estuar Coast Shelf Sci 61:251-259

Lund-Hansen LC, Hai DN, Lam NN, Nielsen MH (2010) Optical properties of a tropical estuary during wet and dry conditions in the Nha Phu estuary, Khanh Hoa Province, south-east Vietnam. Hydrobiologia 644:207-216 doi:10.1007/s10750-010-0114-1

Madhu NV et al. (2007) Monsoonal impact on planktonic standing stock and abundance in a tropical estuary (Cochin backwaters - India). Estuar Coast Shelf Sci 73:54-64

Matos JB, Sodré DKL, Da Costa KG, Pereira LCC, Da Costa RM (2011) Spatial and temporal variation in the composition and biomass of phytoplankton in an Amazonian estuary. J Coast Res:1525-1529

Maurer D, Vargas JA (1984) Diversity of soft-bottom benthos in a tropical estuary: Gulf of Nicoya, Costa Rica. Mar Biol 81:97-106

Morales-Ramírez A (2011) La diversidad marina del Golfo Dulce, Pacífico sur de Costa Rica: Amenazas a su conservación. Biocenosis 24:9-20

Muylaert K, Sabbe K, Vyverman W (2009) Changes in phytoplankton diversity and community composition along the salinity gradient of the Schelde estuary (Belgium/The Netherlands). Estuar Coast Shelf Sci 82:335-340

Nittrouer CA, Brunskill GJ, Figueiredo AG (1995) Importance of tropical coastal environments. Geo-Mar Lett 15:121-126

Nursuhayati AS, Yusoff FM, Shariff M (2013) Spatial and temporal distribution of phytoplankton in perak estuary, Malaysia, during monsoon season. J Fish Aquatic Sci 8:480-493 doi:10.3923/jfas.2013.480.493

Officer CB, Smayda TJ, Mann R (1982) Benthic filter feeding - a natural eutrophication control. Mar Ecol Prog Ser 9:203-210 doi:10.3354/meps009203

Palter J, Coto SL, Ballestero D (2007) The distribution of nutrients, dissolved oxygen and chlorophyll a in the upper Gulf of Nicoya, Costa Rica, a tropical estuary. Rev Biol Trop $55: 427-436$ 
Pamplona FC, Paes ET, Nepomuceno A (2013) Nutrient fluctuations in the Quatipuru river: A macrotidal estuarine mangrove system in the Brazilian Amazonian basin. Estuar Coast Shelf Sci 133:273-284 doi:http://dx.doi.org/10.1016/j.ecss.2013.09.010

Peragallo H, Peragallo M (1897-1908) Diatomées marines de France et des districts maritimes voisins. Micrographie-Editeur, Grez-sur-Loing

Peterson CL (1960) The physical oceanography of the Gulf of Nicoya, Costa Rica, a tropical estuary. Inter-American Tropical Tuna Commission 3:139-188

Quinlan EL, Phlips EJ (2007) Phytoplankton assemblages across the marine to low-salinity transition zone in a blackwater dominated estuary. J Plankton Res 29:401-416 doi:10.1093/plankt/fbm024

Ram ASP, Nair S, Chandramohan D (2003) Seasonal shift in net ecosystem production in a tropical estuary. Limnol Oceanogr 48:1601-1607

Rassoulzadegan F, Laval-Peuto M, Sheldon RW (1988) Partitioning of the food ration of marine ciliates between pico- and nanoplankton. Hydrobiologia 159:75-88

Ricard M (1987) Atlas du Phytoplancton Marin: Diatomophycées. vol 2. Edition du C.N.R.S, Paris

Ritchie RJ (2008) Universal chlorophyll equations for estimating chlorophylls a, b, c, and d and total chlorophylls in natural assemblages of photosynthetic organisms using acetone, methanol, or ethanol solvents. Photosynthetica 46:115-126

Rochelle-Newall EJ et al. (2011) Phytoplankton distribution and productivity in a highly turbid, tropical coastal system (Bach Dang Estuary, Vietnam). Mar Pollut Bull 62:2317-2329 doi:10.1016/j.marpolbul.2011.08.044

Round FE, Crawford, R. M., Mann, D. G. (1990) The Diatoms, Biology and morphology of the genera. Cambridge University Press, Cambridge

Santana DSP, R.S. Pereira, L.C.C. Costa, R.M. da. (2010) Microphytoplankton of the Marapanim Estuary (Pará, Northern Brazil). Trop Oceanograp 38:161-172

Santiago MF, Silva-Cunha MdGGd, Neumann-Leitão S, Costa KMPd, Palmeira GCB, Porto Neto FdF, Nunes FS (2010) Phytoplankton dynamics in a highly eutrophic estuary in tropical Brazil. Braz J Oceanograp 58:189-205

Shaffer GP, Sullivan MJ (1988) Wter column productivity attributable to displaced benthic diatoms in well-mixed shallow estuaries. J Phycol 24:132-140 doi:10.1111/j.15298817.1988.tb04226.x

Shannon CEWW (1963) The mathematical theory of communication. University of Illinois Press, Urbana

Sidik MJ, Rashed-Un-Nabi M, Azharul Hoque M (2008) Distribution of phytoplankton community in relation to environmental parameters in cage culture area of Sepanggar Bay, Sabah, Malaysia. Estuar Coast Shelf Sci 80:251-260 doi:10.1016/j.ecss.2008.08.004

Sin Y, Wetzel RL, Anderson IC (2000) Seasonal variations of size-fractionated phytoplankton along the salinity gradient in the York River estuary, Virginia (USA). J Plankton Res 22:1945-1960

Smayda TJ, Reynolds CS (2003) Strategies of marine dinoflagellate survival and some rules of assembly. J Sea Res 49:95-106 doi:10.1016/s1385-1101(02)00219-8

Soria-Píriz S (2011) Metabolismo neto de la comunidad pelágica del Golfo de Nicoya. University of Cadiz, Cadiz

Stedmon CA, Markager S (2003) Behaviour of the optical properties of coloured dissolved organic matter under conservative mixing. Estuar Coast Shelf Sci 57:973-979 doi:http://dx.doi.org/10.1016/S0272-7714(03)00003-9

Sverdrup HU (1953) On conditions for the vernal blooming of phytoplankton. vol 18. Journal du Conseil International pour l'Exploration de la Mer,

Tomas CR (1997) Editor's Foreword. In: Tomas CR (ed) Identifying Marine Phytoplankton. Academic Press, San Diego, pp ix-x. doi:http://dx.doi.org/10.1016/B978-012693018$\underline{4 / 50000-8}$ 
Tracana BC (1985) Algas del noroeste argentino (excluyendo las Diatomophyceae). Ministerio de Cultura y Educación, Fundación Miguel Lillo, San Miguel de Tucumán, República Argentina

Underwood GJC, Kromkamp J (1999) Primary Production by Phytoplankton and Microphytobenthos in Estuaries. In: Nedwell DB, Raffaelli DG (eds) Advances in Ecological Research, vol 29. Academic Press, pp 93-153. doi:http://dx.doi.org/10.1016/S0065-2504(08)60192-0

Utermöhl H (1958) Zur Vervollkommnung der quantitativen Planktonmethodik. vol 9. Mitteilungen der Internationalen Vereinigung für Theoretische und Angewandte Limnologie,

Vargas JA (1995) The Gulf of Nicoya Estuary, Costa Rica: Past, present, and future cooperative research. Helgoländer Meeresuntersuchungen 49:821-828

Vargas Montero M, Freer Bustamante E, Guzman JC, Carlos Vargas J (2008) Harmful blooms by noxious dinoflagellates in the Pacific coast of Costa Rica. Hidrobiologica 18:15-23

Vargas-Montero M, Freer E (2004) Harmful blooms of cyanobacteria (Oscillatoriaceae) and dinoflagellates (Gymnodiniaceae) in the Golfo de Nicoya, Costa Rica Rev Biol Trop 52:121-125

Víquez R, Hargraves PE (2009) Phytoplankton. Springer Science + Business Media B. V. doi:http://dx.doi.org/10.1007/978-1-4020-8278-8

Voorhis A, Epifanio CE, Maurer D, Dittel A, Vargas J (1983) The estuarine character of the Gulf of Nicoya, an embayment on the Pacific coast of Central America. Hydrobiologia 99:225-237 doi:10.1007/BF00008774

Werner I, Hollibaugh JT (1993) Potamocorbula amurensis: comparison of clearance rates and assimilation efficiencies for phytoplankton and bacterioplankton. Limnol Oceanogr 38:949-964

\section{Figures}

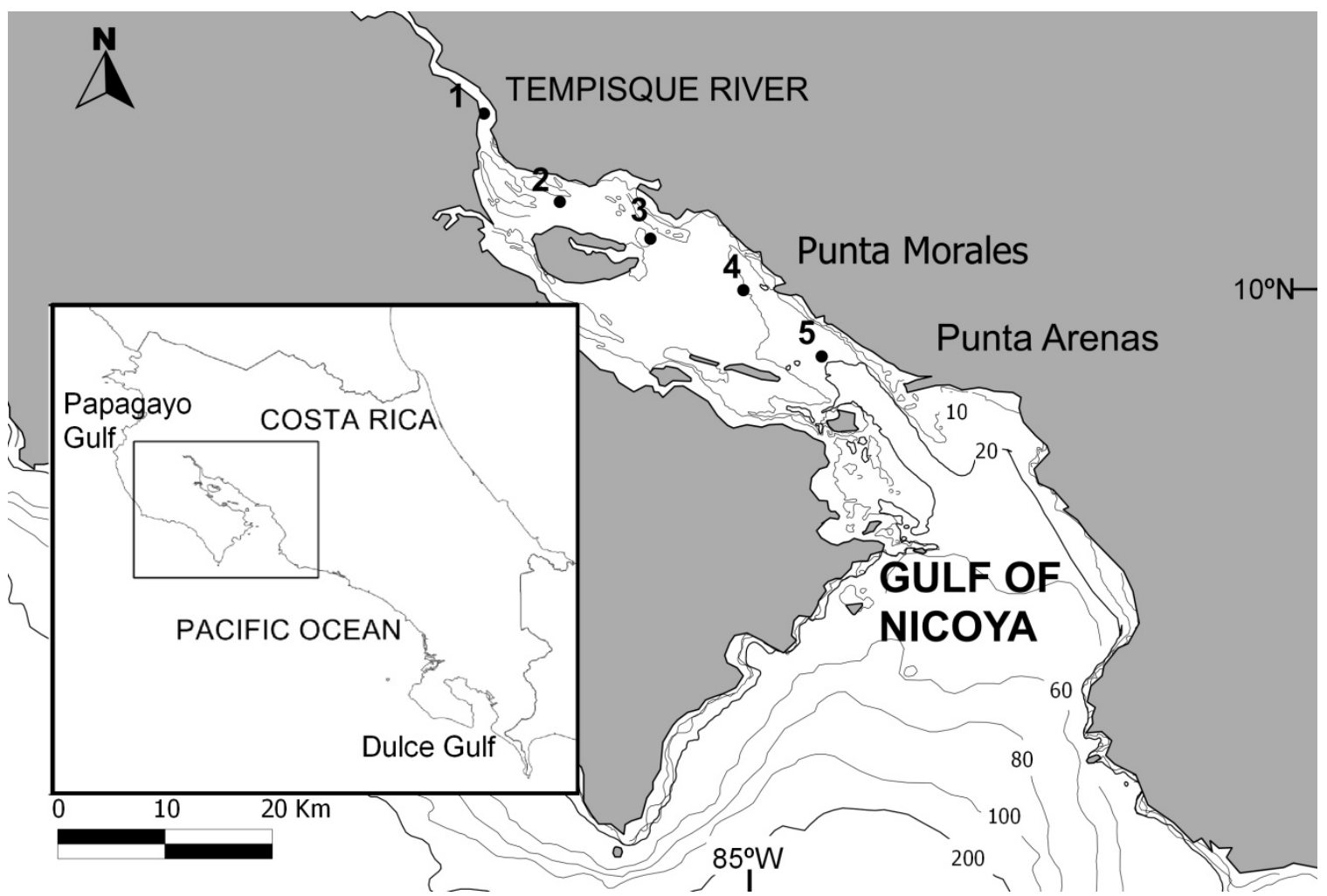

Figure 1. I. Seguro et al. 2015 


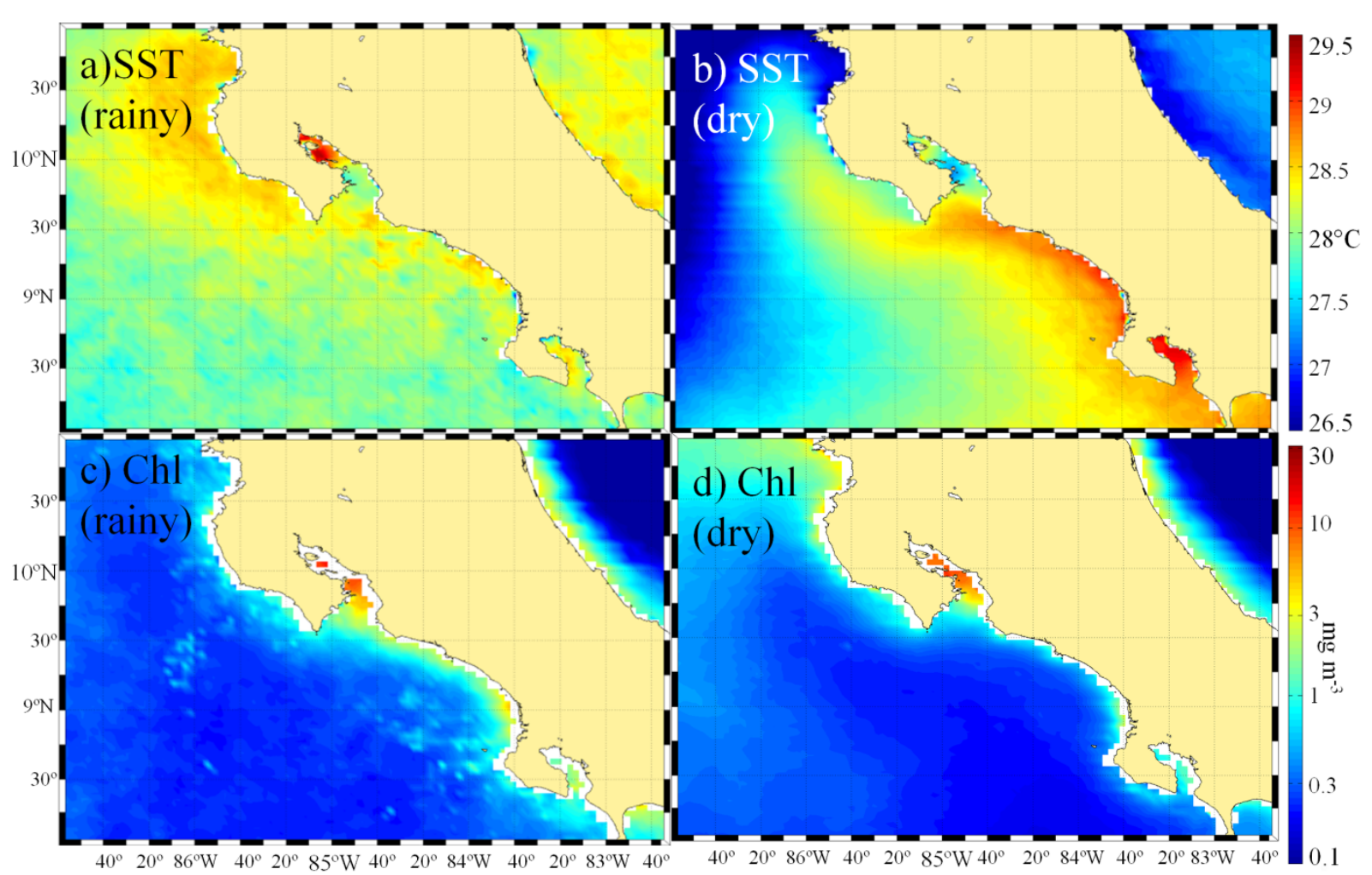

Figure 2. I. Seguro et al. 2015
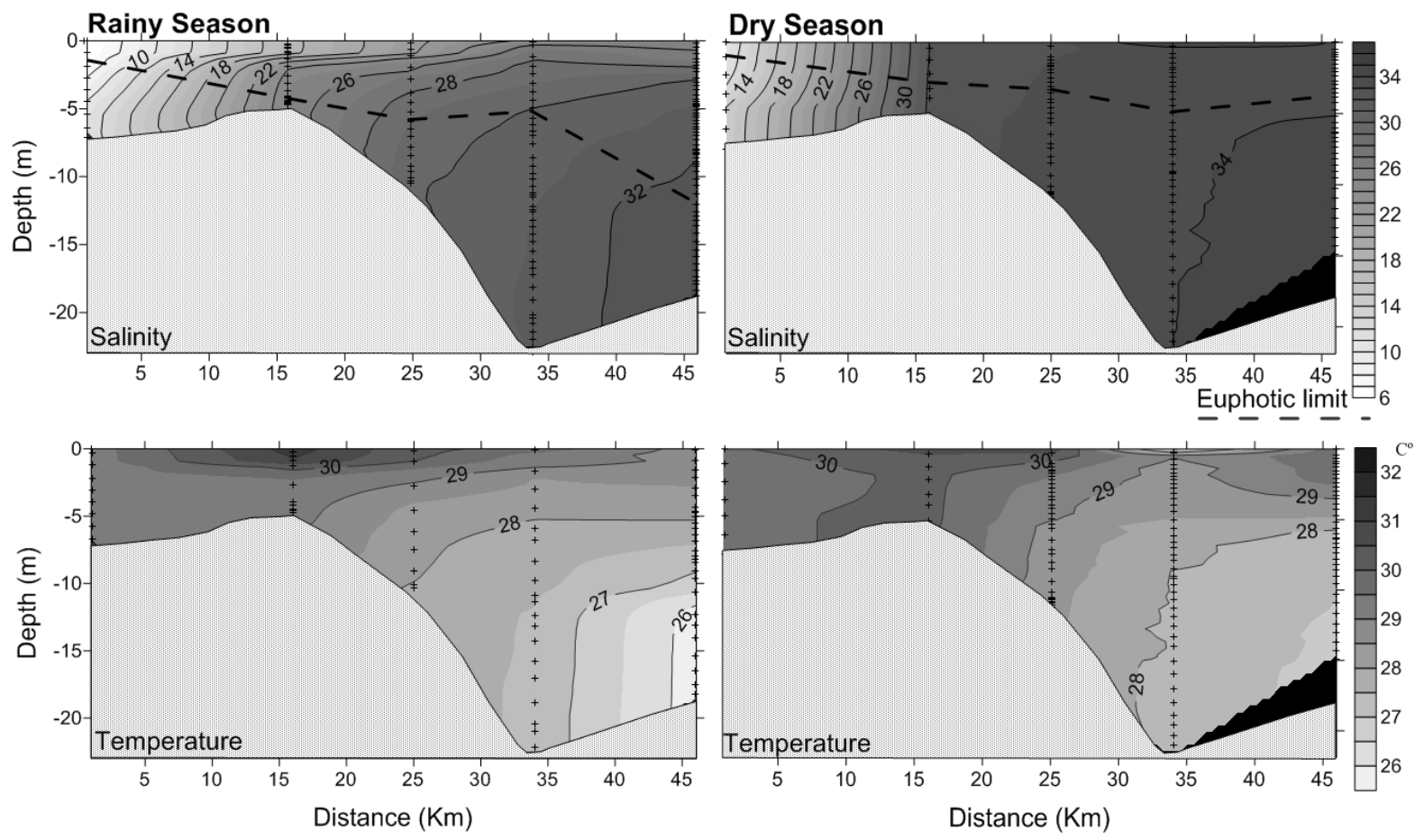

Figure 3. I. Seguro et al. 2015 

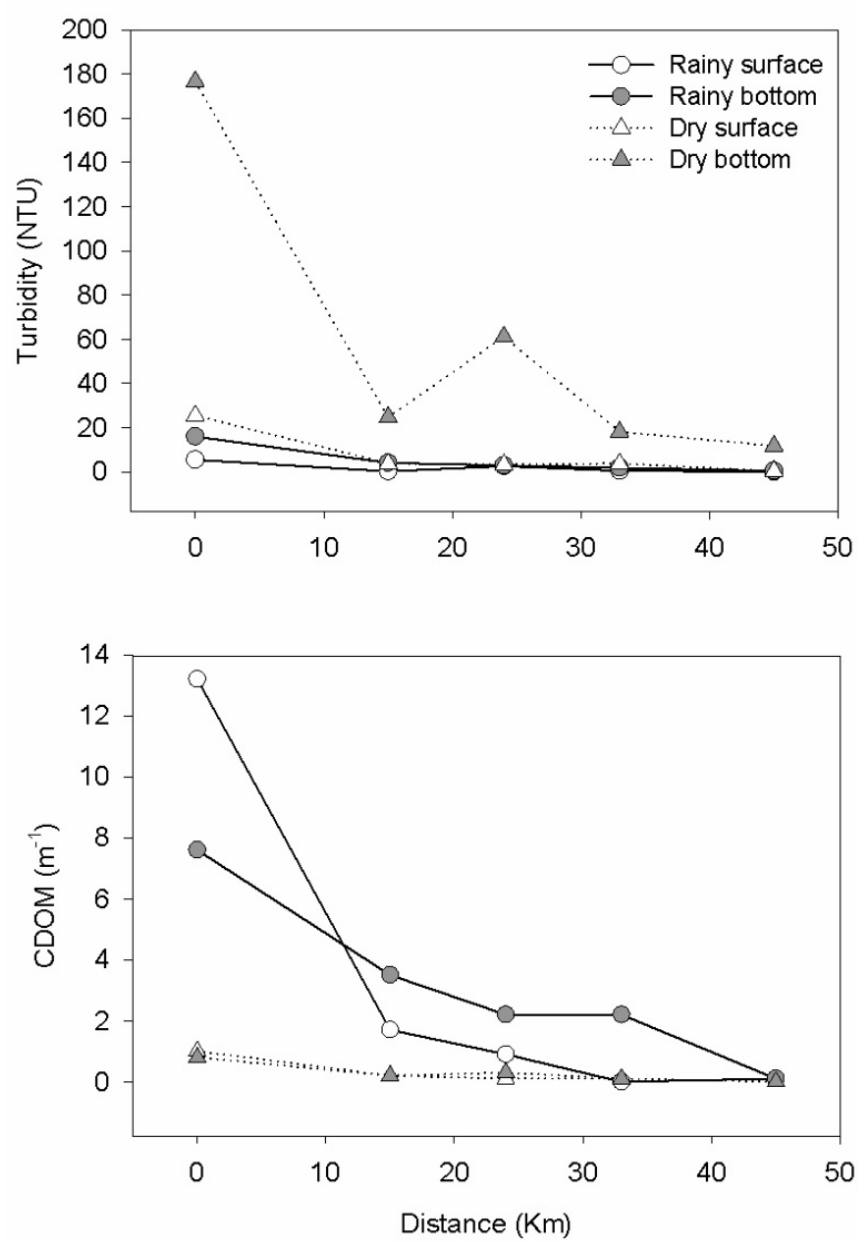

885

886 Figure 4. I. Seguro et al. 2015 

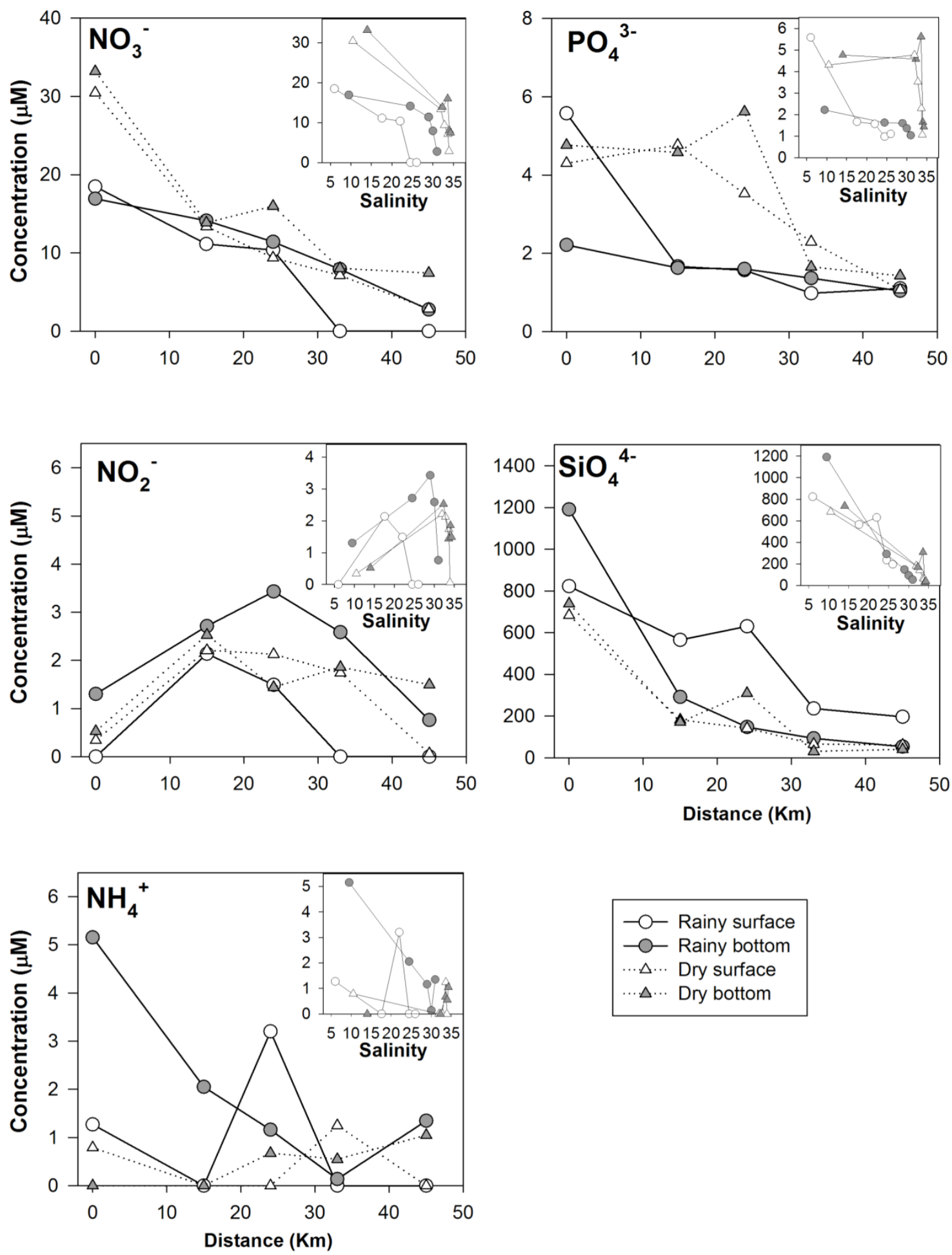

888 Figure 5. I. Seguro et al. 2015 

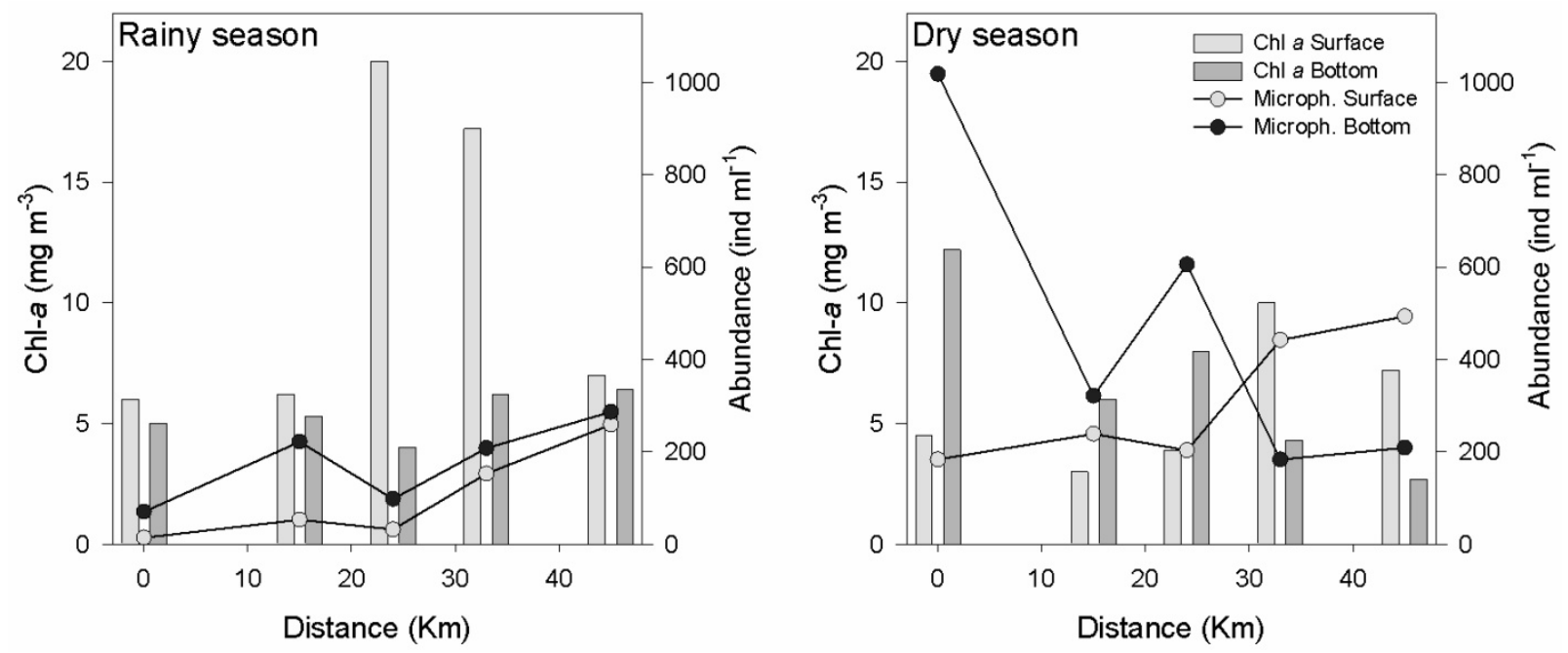

891 Figure 6. I. Seguro et al. 2015
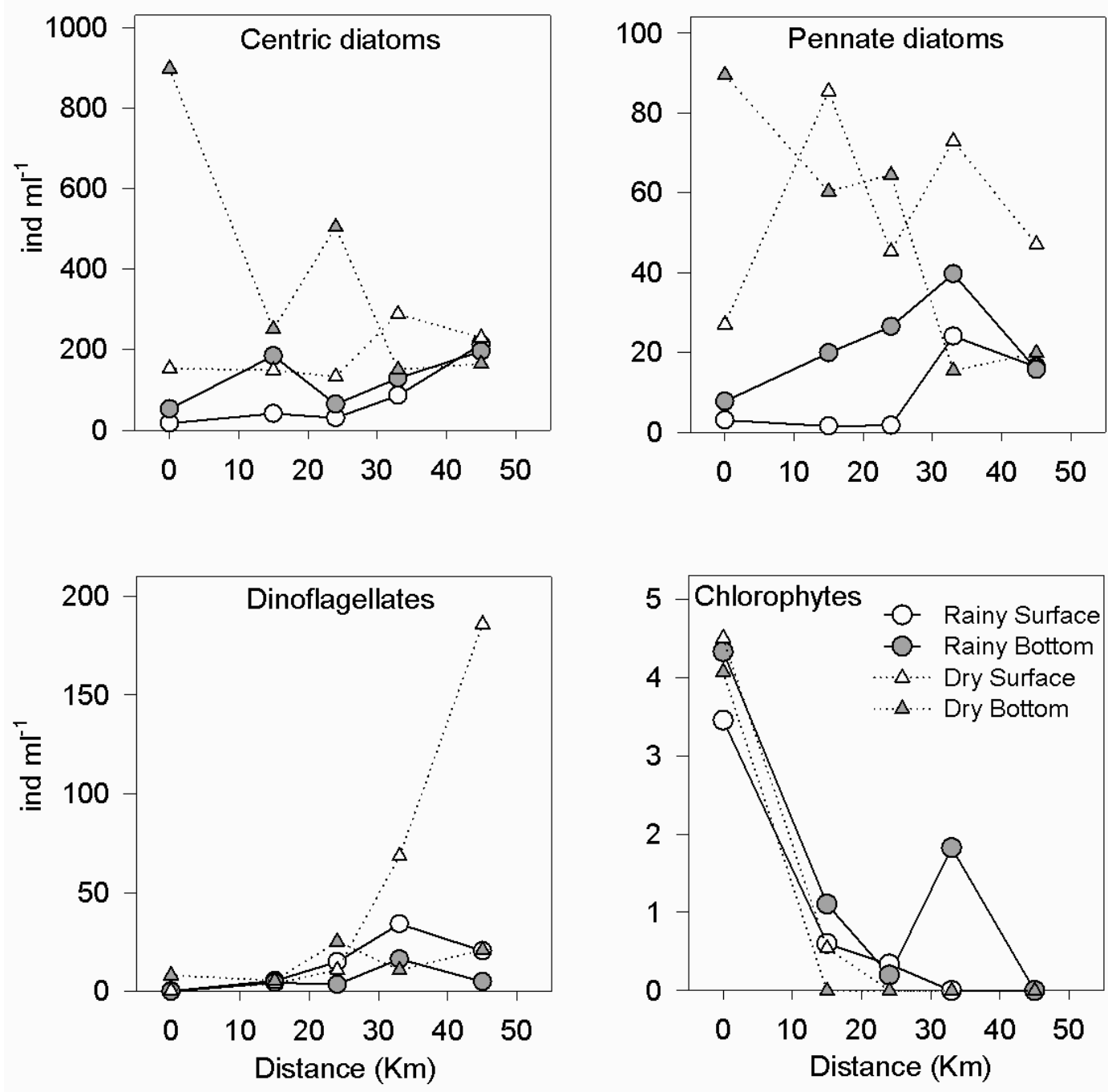

893 Figure 7. I. Seguro et al. 2015 


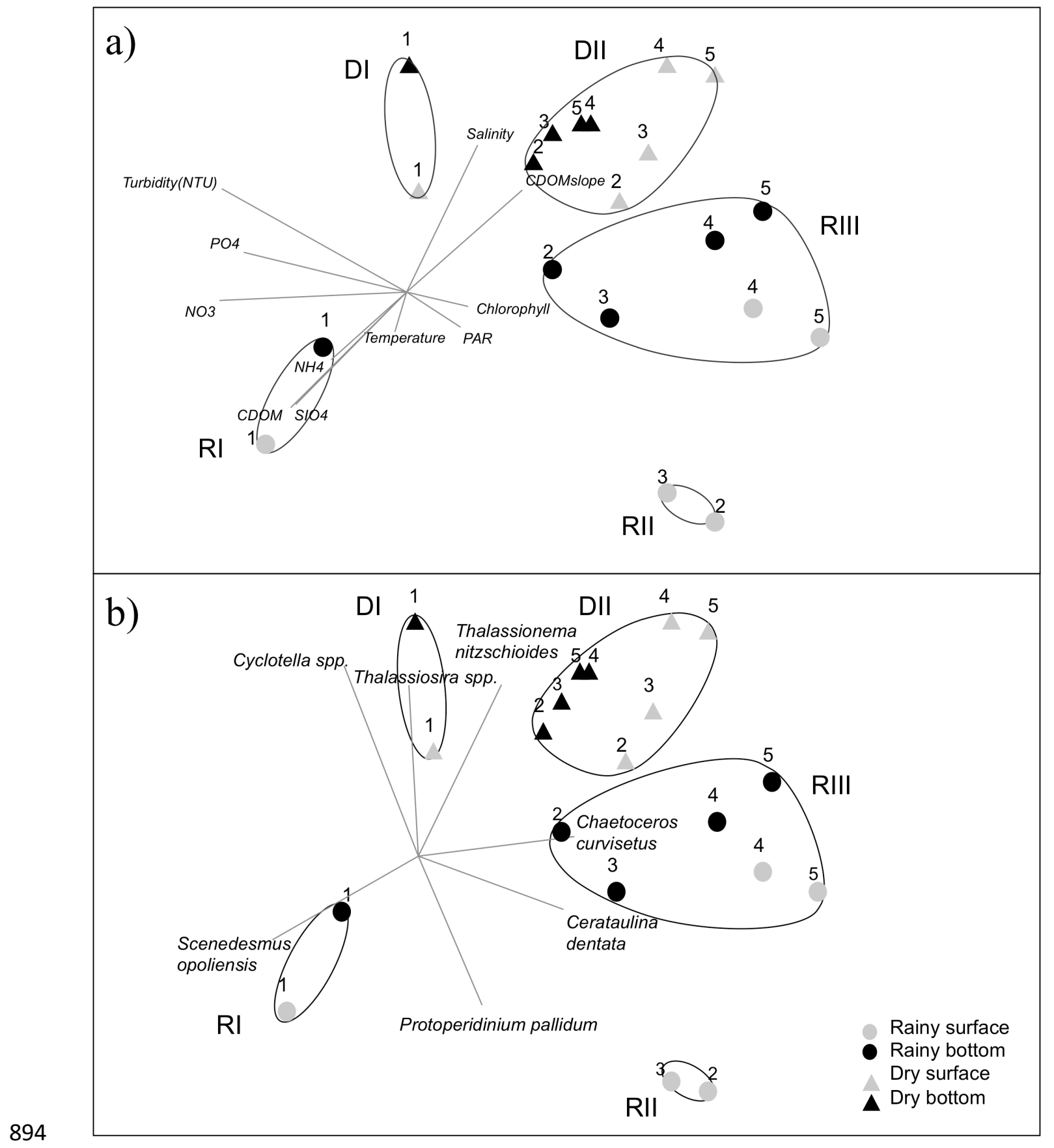

895 Figure 8. I. Seguro et al. 2015

896

897

898

899

900

901

902

903 
904

905

906

907

908

909

910

911

912

913

914

915

916

917

918

919

920

921

922

923

924

925

926

927

928

929

930

\section{Figure Captions}

Fig. 1 Map of the Gulf of Nicoya indicating the five stations sampled in the rainy and dry seasons.

Fig. 2 Sea surface temperature (SST) in ${ }^{\circ} \mathrm{C}(\mathrm{a} \& \mathrm{~b})$ and $(\mathrm{c} \& \mathrm{~d})$ chlorophyll $a(\mathrm{chl} a)$ in $\mathrm{mg} \mathrm{m} \mathrm{m}^{-3}$ (logarithmic scale) (c \& d) along the Pacific Coast of Costa Rica during the rainy and dry season averaged for the period 2002-2011.

Fig. 3 Cross section contour plots of salinity and temperature $\left({ }^{\circ} \mathrm{C}\right)$ along in the inner Gulf of Nicoya versus distance from the river in the rainy and dry season. Crosses represent sampled depths and discontinuous line the limit of the euphotic zone.

Fig. 4 Temporal and spatial variation in turbidity (NTU) and CDOM $\left(\mathrm{m}^{-1}\right)$ along the five stations in the inner Gulf of Nicoya for the surface and bottom layers in the rainy and dry season.

Fig. 5 Temporal and spatial variation of $\mathrm{NO}_{3}{ }^{-}, \mathrm{NO}_{2}{ }^{-}, \mathrm{NH}_{4}{ }^{+}, \mathrm{PO}_{4}{ }^{3-}$ and $\mathrm{SiO}_{3}{ }^{3-}$ concentrations $(\mu \mathrm{M})$ along the five stations in the inner Gulf of Nicoya for the surface and bottom layers during the rainy and dry season. The nutrient vs salinity relationship is presented as inserted plots.

Fig. 6 Temporal and spatial variation of $\operatorname{chl} a\left(\mathrm{mg} \mathrm{m}^{-3}\right)$ and microplankton abundance (ind $\left.\mathrm{mL}^{-1}\right)$ along the five stations in the inner Gulf of Nicoya for the surface and bottom layers during the rainy and dry season. Distance is calculated starting from the most riverine station.

Fig. 7 Temporal and spatial variation of main taxonomic groups. Abundance (ind $\mathrm{mL}^{-1}$ ) along the five stations in the inner Gulf of Nicoya for the surface and bottom layers during the rainy and dry season. Distance is calculated starting from the most riverine station.

Fig. $8 \log (x+1)$ transformed microplankton abundance data along the five stations in the inner Gulf of Nicoya for the surface and bottom layers during the rainy and dry season. (Stress: 0.11). Circles indicate groups (Group I-V) at a similarity level of $48 \%$ derived from cluster analysis. Vectors indicate direction and relative magnitude of Spearman correlation with the plot axes of (a) the environmental variables $>0.5$ and (b) the species abundance $(>0.7)$. 
934 surface and bottom layers in the rainy and dry season. Diversity values for the five assemblages (DI, DII,

935 RI, RII and RIII) obtained from the SIMPROF routine during cluster analysis are also shown. Shannon 936 diversity index was calculated according to Shannon and Weaver (1963) using the following equation: $937 \quad H=-\sum_{i=1}^{S} p_{i} \operatorname{Ln}\left(p_{i}\right)$

938

$\begin{array}{lllll}1 & 2 & 3 & 4 & 5\end{array}$

\begin{tabular}{lcccccc}
\hline Rainy season & & & & & & \\
& Surface & 2.40 & 2.20 & 2.80 & 2.44 & 1.97 \\
& Bottom & 2.32 & 2.45 & 2.36 & 2.90 & 2.56 \\
\hline Dry season & & & & & 2.45 \\
& Surface & 1.91 & 2.22 & 2.30 & 2.75 & 2.60 \\
& Bottom & 1.70 & 1.86 & 1.72 & 2.15 & RIII
\end{tabular}

939 
953 along the five stations in the inner Gulf of Nicoya in the rainy and dry season. Abundance data were first 954 transformed to microplankton biovolume from mean size of most abundant taxa (Hillebrand et al., 1999, 955 López-Fuerte and Siqueiros-Beltrones 2006) and then to biomass ( $\left.\mu \mathrm{g} \mathrm{C} \mathrm{L}^{-1}\right)$ using conversion factors 956 (Eppley et al. 1970, Leblanc et al. 2012). Similarly, autotrophic picoplankton and nanoplankton 957 biomasses were calculated from measured abundance and size of both communities using flow cytometry 958 in a complementary study (Aguilar et al. in prep.). Picoplankton and nanoplankton abundance and size 959 were transformed from biovolume to biomass, in C units, using available conversion factors (DuRand et 960 al. 2001, Shalapyonok et al. 2001, Worden et al. 2004)

961

\begin{tabular}{lcccc} 
Rainy season & & Picoplankton & Nanoplankton & Microplankton \\
\hline Biomass $\left(\mu \mathrm{g} \mathrm{C} \mathrm{L}^{-1}\right)$ & $\bar{x} \pm \mathrm{SE}$ & $14.32 \pm 6.14$ & $1642.79 \pm 369.77$ & 171.9 \\
$\%$ & & 0,78 & 89.81 & 9,4 \\
Dry season & & & & \\
\hline Biomass $\left(\mu \mathrm{g} \mathrm{C} \mathrm{L}^{-1}\right)$ & $\bar{x} \pm \mathrm{SE}$ & $5.26 \pm 1.33$ & $1019.43 \pm 179.76$ & 207.8 \\
$\%$ & & 0.43 & 82.7 & 16.9
\end{tabular}

